Przegląd Badań Edukacyjnych Educational Studies Review

ISSN 1895-4308

nr 28 (1/2019), s. 23-35

ORYGINALNE ARTYKUtY BADAWCZE

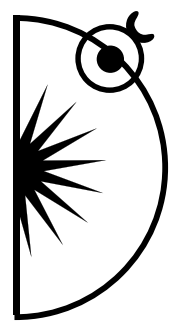

Magdalena Zadworna-Cieślak

ORCID: 0000-0002-0585-019X

University of Lodz; e-mail: magdalena.zadworna@uni.lodz.pl

Nina Ogińska-Bulik

ORCID: 0000-0001-8868-407X

University of Lodz; e-mail: janina.oginska@uni.lodz.pl

\title{
Satisfaction with Life in Old Age - the Role of Developmental Tasks Attainment and Resiliency
}

http://dx.doi.org/10.12775/PBE.2019.002

\begin{abstract}
The late adulthood period is full of challenges which endanger the well-being of an individual and require adaptation. Personal factors such as resiliency and the attainment of developmental tasks typical for the age period play therefore key roles in achieving life satisfaction in old age. The aim of the present study was to determine the roles of resiliency and developmental task attainment in achieving satisfaction with life in old age.

One hundred participants of Senior Clubs in their late adulthood, 49 men and 51 women (age range $60-88$ years; $\mathrm{M}=70.57, \mathrm{SD}=6.71$ ) were surveyed using the Satisfaction with Life Scale (SWLS), Resiliency Measurement Scale (SPP-25) and Developmental Tasks Questionnaire for Seniors (KZR-S).

The relationships between variables were determined by correlation, regression analysis and structural equation modeling. The analyses revealed significant relationships between variables. Greater overall resiliency and higher levels of developmental task attainment were associated with greater satisfaction with life, as declared by the respondents. The most significant ones seem to be determination and persistence in action (resiliency factor) and acceptance of one's life: components of developmental task attainment.

Both resiliency and developmental task attainment have a positive impact on the life satisfaction of older people. Greater importance should be attributed to resiliency.
\end{abstract}

Key words: satisfaction with life, old age, seniors, developmental tasks, resiliency. 


\section{Introduction}

\section{Satisfaction with life in late adulthood}

Current demographic trends, characterized by a growing proportion of elders and increasing life expectancy, have fuelled greater interest in the period of late adulthood, and increasing numbers of studies are examining the basis of a "successful old age". The period after the age of 60 can be very heterogeneous, and people in this time of their life demonstrate a wide range of functioning (Zadworna-Cieślak, Marszałek, 2017). The period is characterized by many changes and challenges requiring the individual to adapt. Although many can function optimally and enjoy the "autumn of their life", old age can also be beset by disability, dependence, depression and, above all, reduced quality of life.

Life satisfaction is a key element of the concept of successful aging. Attempts to define and describe factors responsible for this process have been made since the 1960s. Most of these are described by models oscillating around social functioning in old age, definitions highlighting satisfaction with life, models emphasizing psychological resources, medical theories focused on the length of a healthy life and the so-called colloquial definitions created by the subjects (Bowling, 2007). Of these the level of satisfaction with life is often regarded as a universal indicator of successful aging (Villar, 2012).

Satisfaction with life is, however, defined in various ways depending on the context, and is often used interchangeably with the term quality of life, and opinions differ in this area (Dziurowicz-Kozłowska, 2002; Halicka, 2004). Satisfaction with life can be considered as one of the elements of the subjective well-being of the individual, which is composed of positive and lack of negative feelings (Diener et al., 1985; Pavot and Diener, 1993); this arises from a comparison being made between the personal situation of an individual with standards set on the basis of personally-set criteria. In this sense, life satisfaction is the process of making a cognitive global assessment of one's past life.

Generally, older people have been found to possess high levels of life satisfaction. Halicka (2004) reports that the majority of respondents involved in the study declared that they were satisfied or very satisfied with their lives and assessed their life achievements more positively than their current situation.

Satisfaction with life in the late adulthood period depends on many objective and subjective factors, including the living conditions, health status, psychological factors, multidimensional support and psychosocial development, and the balance of life achievements and losses (Zielińska-Więczkowska, Kędziora-Kornatowska, 2010). 


\section{Developmental task attainment in late adulthood}

Developmental tasks can be considered as challenges that people confront in a certain age period and serve as important determinants of the course of normal development and its effects (Hutteman et al., 2014). The sources of developmental tasks are biological changes related to age, as well as cultural tradition and individual aspirations. The effective implementation of developmental tasks provides the individual with a sense of satisfaction, and this can be the basis for making conclusions about the normativity of individual development. However, difficulties in the attainment of such tasks, especially long-term ones, may lead to a deterioration in the sense of well-being and can imply a lack of normativity and punctuality of development to the individual. In this case, the individual's life will be separated from established cultural patterns and biological rhythms, which may lead to the development of maladaptation symptoms.

The concept of developmental tasks (Havighurst, 1981) is one of the first to show human development as a lifelong process, consisting of many aspects of human activity in the form of developmental tasks. Havighurst proposes that, for individuals aged over 60 , these tasks include adapting to a decline in physical strength, adapting to retirement and reduced income, reconciliating oneself with the death of a spouse, maintaining social relationships with people of one's own age, accepting and adapting for changing social roles and adjusting to physical living conditions. In the light of this concept, quality of life in the senior period results not only from completing such undertaken activities but also includes the need to withdraw. The most significant of these activities involves the continuation of behavioral styles typical of earlier periods of life and the implementation of personal plans and needs, as well as coping with reduced physical and mental capabilities, the loss of relatives and lower material standards.

On the other hand, in his theory of developmental crises, Erikson (2002) highlights the need for individuals in late adulthood to take their place on the integrity - despair continuum. Deteriorating health places an elderly person between two strong conflicting tendencies: the desire to achieve a sense of meaning, a "well-lived life" and to achieve a sense of integrity on the one hand, and the tendency to give in to despair and hopelessness on the other. To resolve the two opposing tendencies, the individual integrates previous life stages and comes to terms with its resultant identity. Achieving such integrity involves believing that the past life made sense. This can be realized from the wider perspective of a re-synthesis of life experiences, feeling the balance of one's own life; if such synthesis is accompanied by acceptance, it helps the individual to overcome the fear of passing and death. 
In this light, the tasks of the late adulthood period include managing physical body changes, directing energy to new roles, accepting one's life and shaping a view regarding death (Newman, Newman, 1984). Erikson regards old age as the culmination of a lifetime of development. Living in accordance with the challenges of age, combined with adaptation to old age and subjective factors, make up a foundation for successful aging, together with other elements of lifestyle, health, social support, and sociodemographic factors (cf. Kozerska, 2015).

\section{The role of resiliency in human functioning}

In light of available empirical data, one of the predictors of life satisfaction at the final stage of life is represented by personal factors (Finogenow, 2008; Magee, Miller, Heaven, 2013). One such factor is resiliency; however, this should not be confused with resilience. While resilience is identified as the process of successfully overcoming negative life events, and in this sense is also referred to as mental resistance, resiliency refers to a personality trait or a relatively permanent individual resource. Ogińska-Bulik and Juczyński (2008) understand resiliency as a mechanism of self-regulation, covering cognitive (e.g. beliefs and expectations), emotional (positive affect and emotional stability) and behavioral elements (seeking new experiences and undertaking various strategies for coping with problems). In this sense, resiliency promotes persistence and flexible adaptation to the requirements of life, increases the tolerance of negative emotions and failures and strengthens a positive attitude to life; in addition, it perceives problems as challenges and opportunities, and the individual as having an influence on decision making.

Research in various adult groups indicates that resiliency is associated with general life satisfaction and satisfactions in various areas (e.g. Ogińska-Bulik, 2014; Beutel et al. 2009; Beutel et al., 2010; Liu, Wang, Li, 2012). Studies also confirm the importance of resiliency for optimal human functioning in the late years of life; for example, in adopting pro-health behaviors (Ogińska-Bulik, Zadworna-Cieślak, Rogala, 2015).

The nature of the relationships between life satisfaction, resiliency and developmental task attainment in senior age has not been the subject of empirical research so far. Hence, the aim of the present study was to determine the role of resiliency and developmental task attainment in achieving life satisfaction among seniors. 


\section{Materials and methods}

A group of 100 people in the late adulthood period, i.e. $60-88$ years $(\mathrm{M}=70.57$, $\mathrm{SD}=6.71)$ was examined. The group included 49 men $(49 \%)$ and 51 women $(51 \%)$.

The participants of the study were members of senior clubs in the city of Lodz. The study was conducted directly during club meetings. The research was voluntary and anonymous. Participants were informed about the confidentiality of the collected data. Of the respondents, $23 \%$ had completed higher education, $16 \%$ general secondary education, $19 \%$ secondary vocational, $32 \%$ vocational, and the remaining $10 \%$ basic education. Over half of the participants $(53 \%)$ were married, $32 \%$ were widowers/widows, $4 \%$ were in informal relationships and $11 \%$ did not have a partner.

Three research tools were used in the study

Life satisfaction was measured using the Satisfaction with Life Scale (SWLS) authored by Diener, Larson, and Griffin (Polish adaptation - Juczyński, 2009). The tool consists of five statements assessed on a 7-point scale (from 1 I strongly disagree, up to 7 - I completely agree) and is used to assess the cognitive aspect of life satisfaction.

Resiliency was tested using the Resiliency Measurement Scale (SPP-25) by Ogińska-Bulik and Juczyński (2008). The scale measures the overall level of resiliency, treated as a personal trait, and its five component parts: 1. Determination and persistence in action, 2. Openness to new experiences and sense of humour, 3. Competencies to cope with and tolerance of negative affect, 4 . Tolerance of failures and treating life as a challenge and 5.Optimistic life attitude and ability to mobilize in difficult situations.

The Developmental Tasks Questionnaire for Seniors (Zadworna-Cieślak, 2017) was used for assessing the level of developmental task attainment in old age. It is a tool designed for people over 60 years of age and measures the general level of developmental task attainment as well as three categories: acceptance of one's life, adaptation, and acceptance of passing. Acceptance of one's life allows for the assessment of the accepting attitude toward one's own life, and positive life outcome. Adaptation refers to adaptive behaviour, i.e. adapting to changes typical of old age such as a decrease in physical strength, retirement and its related reduced income and maintaining social contact; however, it also includes recognition of the need to enlist the help of others if necessary. Acceptance of passing is associated with the reconciliation with the im- 
minence of aging and the inevitability of death, both one's own and that of one's loved ones.

\section{Study results}

In the first stage of the analysis, the mean level of life satisfaction was calculated $(\mathrm{M}=20.40, \mathrm{SD}=5.86)$, which after referring to norms (Juczyński, 2009) was found to correspond to the level of 5 sten. No statistically significant differences in the level of life satisfaction were found according to $\operatorname{sex}(t=1.70, p=0.09)$, level of education $(\mathrm{r}=0.09, \mathrm{p}=0.35)$ or age $(\mathrm{r}=0.04, \mathrm{p}=0.66)$. In order to estimate the role of marital status, the respondents were divided into two subgroups: people living alone $(\mathrm{N}=43)$ and those remaining in relationships $(\mathrm{N}=57)$. The people living in relationships tended to be more satisfied with their lives $(M=21.54, S D=5.77)$ than those who lived alone $(M=18.88$, $\mathrm{SD}=5.70, \mathrm{t}=-2.29, \mathrm{p}=0.02)$.

The overall resiliency score $(\mathrm{M}=69.40, \mathrm{SD}=17.3)$ was found to be average according to the norms for SPP-25 (Ogińska-Bulik, Juczyński, 2008), corresponding to the value of 5 sten.

The overall level of developmental task attainment $(\mathrm{M}=57.64, \mathrm{SD}=9.13)$ was similar to the mean result obtained in tool validation studies (ZadwornaCieślak, 2017).

Following this, the correlation coefficients between the variables were calculated (Table 1 and 2).

Tab. 1. Correlation coefficients between life satisfaction and developmental task attainment in the research group

\begin{tabular}{|c|c|c|c|c|}
\hline VARIABLES & $\begin{array}{c}\text { Developmental } \\
\text { tasks attainment }- \\
\text { general score }\end{array}$ & $\begin{array}{c}\text { Acceptance of } \\
\text { one's life }\end{array}$ & Adaptation & $\begin{array}{c}\text { Acceptance of } \\
\text { passing }\end{array}$ \\
\hline $\begin{array}{c}\text { Satisfaction with } \\
\text { life }\end{array}$ & $\begin{array}{c}.334 \\
* *\end{array}$ & $\begin{array}{c}.392 \\
* * *\end{array}$ & $\begin{array}{c}.128 \\
\mathrm{~ns}\end{array}$ & $\begin{array}{c}.221 \\
*\end{array}$ \\
\hline
\end{tabular}

Notes: ${ }^{*} p<0.05^{* *} p<0.01{ }^{* * *} p<0.001$; ns - not significant

Source: Authors' research.

The data in the table indicted a positive relationship between developmental task attainment and life satisfaction among seniors. It appears to be more closely related to Acceptance of one's life than Acceptance of passing. Greater acceptance of the past life by a senior and greater reconciliation with the inevitability of aging and death is associated with greater declared satisfaction with 
life. No significant relationship was found between satisfaction with life and Adaptation as a factor of developmental task attainment.

Tab. 2. Correlation coefficients between life satisfaction and resiliency in the research group

\begin{tabular}{|c|c|c|c|c|c|c|}
\hline VARIABLES & $\begin{array}{l}\text { Resiliency } \\
\text { - general } \\
\text { score }\end{array}$ & F. 1. & F. 2. & F. 3. & F. 4. & F. 5. \\
\hline $\begin{array}{l}\text { Satisfaction } \\
\text { with life }\end{array}$ & .457 & .441 & .403 & .401 & $\begin{array}{l}.419 \\
* \star \star\end{array}$ & $\begin{array}{l}.373 \\
* * *\end{array}$ \\
\hline
\end{tabular}

Notes:

${ }^{* * *} \mathrm{p}<0.001$; F. 1. Determination and persistence in action, F. 2. Openness to new experiences and sense of humour, F. 3. Competencies to cope with and tolerance of negative affect, F. 4. Tolerance of failures and treating life as a challenge and F. 5. Optimistic life attitude and ability to mobilize in difficult situations.

Source: Authors' research.

The general level of resiliency, and all of its factors, were found to positively correlate with the satisfaction with life declared by the seniors. In the case of resiliency factors, the highest correlation coefficient was obtained in the field of Determination and persistence in action: a higher the level of resiliency was associated with greater satisfaction with life in late adulthood.

In the next stage of the analysis, the determinants of life satisfaction were established in the course of multiple regression (stepwise method). The general scores of variables were entered in the regression model (step 1), and then the categories of resiliency and developmental tasks implementation were added (step 2) to establish their predictive role (Table 3).

Tab. 3. Determinants of life satisfaction

\begin{tabular}{|c|c|c|c|c|c|}
\hline & Beta & B & Error B & $\mathrm{t}$ & $\mathrm{p}$ \\
\hline & \multicolumn{5}{|c|}{$\begin{array}{c}\text { Stage } 1 \text { - entered variables: general level of resiliency and } \\
\text { developmental task implementation }\end{array}$} \\
\hline Resiliency - general score & 0.41 & 0.14 & 0.03 & 4.74 & 0.00 \\
\hline $\begin{array}{l}\text { Developmental task attainment - } \\
\text { general score }\end{array}$ & 0.27 & 0.17 & 0.05 & 3.06 & 0.00 \\
\hline $\begin{array}{l}\text { Eigenvalue } \\
R=0.53 ; R 2=0.28\end{array}$ & & 0.81 & 3.57 & 0.23 & 0.82 \\
\hline
\end{tabular}

Stage 2 - entered variables: factors of resiliency and developmental task implementation

Determination and persistence in action (Factor of resiliency)

0.43

0.65

0.13

5.17

0.00 
Tab. 3. cd.

\begin{tabular}{lccccc}
\hline & Beta & B & Error B & $t$ & $\mathrm{p}$ \\
\hline $\begin{array}{l}\text { Acceptance of one's life } \\
\text { (Factor of developmental tasks) }\end{array}$ & 0.38 & 0.53 & 0.12 & 4.55 & 0.00 \\
\hline $\begin{array}{l}\text { Eigenvalue } \\
\mathrm{R}=0.58 ; \mathrm{R} 2=0.34\end{array}$ & & 0.91 & 2.85 & 0.32 & 0.75 \\
\hline
\end{tabular}

Source: Authors' research.

The data presented in Table 3 indicate that the values for both overall level of resiliency and implementation of development tasks can be used as predictors of life satisfaction; however, resiliency explains the variance of the dependent variable to a greater extent $(21 \%)$. More precisely, Determination and persistence in action, a factor of resilience, and Acceptance of one's life, a category associated with the implementation of developmental tasks acted as determinants of life satisfaction: the former explains $19 \%$ of the variance of the dependent variable while the second explains $15 \%$.

In the final stage of the analysis, a structural model of relations between variables was created using the path analysis method (Figure 1). Different alternative models were tested, the model presented below proved to be the best theoretically suited, the most economical and the best one for the data $\left(\chi^{2}=0.63\right.$, $\mathrm{df}=1, \mathrm{p}=0.43, \mathrm{RMSEA}=0.001, \mathrm{NFI}=0.992, \mathrm{CFI}=1.000)$.

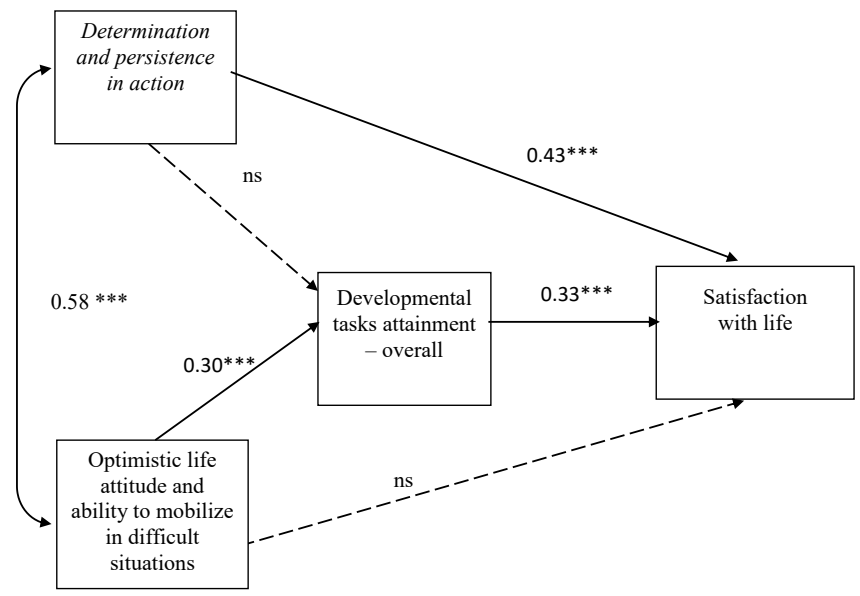

Notes:

${ }^{*} \mathrm{p}<0.05^{* *} \mathrm{p}<0.01{ }^{* * *} \mathrm{p}<0.001$; ns - not significant

Fig. 1. Structure of relations between variables - results of path analyses.

Source: Authors' compilation. 
As indicated in the model above, the level of satisfaction with life is directly affected by the overall level of developmental task attainment and the resiliency factor Determination and persistence in action. Another resiliency factor, Optimistic life attitude and ability to mobilize in difficult situations, affects satisfaction with life only indirectly, strengthening the level of implementation of development tasks by the senior. Both resiliency factors are positively correlated with each other.

\section{Discussion of Results and Conclusions}

The surveyed seniors reported an intermediate level of satisfaction with life. A previous study of people aged over 60 by Świerżewska (2010) also revealed a similar level of life satisfaction, as well as a lack of any significant gender differences.

Among the sociodemographic variables, only remaining in a relationship was found to differentiate the level of life satisfaction. Similar data have also been obtained in other studies of the elderly (Alexandre et al., 2009). In addition, satisfaction with life has been found to be strongly related to marital status and age for groups of people at various stages of adult life including late adulthood (Beutel, et al. 200; Beutel et al., 2010). However, although our present findings do not confirm this, they were obtained from a study group comprising solely seniors, which changes the perspective of the impact of age. The chronological age in late adulthood seems to have less impact on life satisfaction. In this age group, a subjective feeling of one's age, i.e. as being younger than one's calendar age, appears to be one of the dominant determinants of life satisfaction, together with the state of health and the level of achievement of undertaken activities (Alexandre et al., 2009; Zielińska-Więczkowska, Kędziora-Kornatowska, 2010).

Satisfaction with life among older people correlates undeniably with many personality traits. In our research, resiliency was significantly positively correlated with the level of life satisfaction. An elderly person who has a high level of resiliency, i.e. someone who copes well with stress and easily adapts to changing living conditions, has a higher level of satisfaction with life.

The positive influence of resiliency on life satisfaction is probably also associated with its connections with other individual resources such as dispositional optimism, sense of coherence or self-esteem, which are considered to be conducive to well-being. In addition, resiliency also promotes effective coping (Ogińska-Bulik, Juczyński, 2008), which can be a source of satisfaction and positive self-esteem. In this context, our present findings are consistent with 
those of other empirical reports that take into account individual personal resources as supporting life satisfaction of seniors. For example, the study conducted by Świerżewska (2010) included dispositional optimism, basic hope and emotional intelligence.

It is important to mention that the positive relationship between resiliency and life satisfaction seems to be independent of age. This has also been shown in groups of teenagers (Ogińska-Bulik, 2010).

Resiliency is also associated with the occurrence of positive emotions which strengthen health and quality of life. The significance of positive emotions for well-being, both physical and mental, is highlighted by, among others, Fredrickson (2001) in her Broaden-and-Build Theory of Positive Emotions. She proposes that experiencing positive emotions increases creativity, openness to new information, flexibility and efficiency of thinking and increases the ability to integrate various information. Better cognitive functioning can also increase the sense of life satisfaction. Sęk (2008) emphasizes that positive emotions increase physical immunity, thus bolstering physical health, and are an important factor in shaping mental well-being. They also foster the development of resources, including resiliency, that can be used to deal with future challenges.

Our present findings also indicate that more efficient implementation of tasks typical of their age by older people, such as accepting their current life and agreeing with the inevitability of passing, is associated with a higher level of satisfaction with life. Brudek (2017) reports that satisfaction with life by seniors positively and strongly correlates with their life balance, which also plays a mediating role in the relationship between personality traits and quality of life of older people. These conclusions can be referred to the results of the structural modeling equations given in the present study. The attainment of the developmental tasks of late adulthood, part of which is life balance making, a construct similar to the factor Acceptance of one's life, plays a mediating role between one of the factors of resiliency and satisfaction with life. Resiliency and its components directly affect the life satisfaction of seniors, as well as indirectly by strengthening the implementation of development tasks. Personality traits and self-activities consistent with the challenges of the developmental period are important for achieving well-being in the later years of life. Similarly, Dezutter et al. (2013) established a positive relationship between the sense of coherence and life satisfaction, where ego integrity, understood by Erikson as a developmental task, proved to be the mediating factor.

Our research has some limitations, one of which is the small size of the sample and its limited variation. In addition, the research was of a cross-sec- 
tional nature, which limits the possibility of determining cause-and-effect relationships. In the future, an interesting aspect of research would be to compare seniors with diverse activities and lifestyles; all members of the group studied herein participated in senior clubs, which may affect its functioning and question the extrapolation of the obtained results to a wider population of older people.

Nevertheless, our study brings new, original content into the area of knowledge concerning the quality of life in its late years. The topic of developmental task attainment has yet to be addressed in empirical studies, and so the interpretation of our results requires the use of data derived from studies of similar but not identical constructs. In addition, our findings allow for important practical conclusions to be drawn. Supporting seniors in the efficient implementation of developmental tasks and strengthening their personal resources may affect their satisfaction with life during late adulthood. Hence, psycho-preventive and educational interactions should be adapted to the development period. Personal resources such as resiliency can be strengthened at any age through psychological intervention, psychoeducation and multidimensional support (Luthans, Vogelgesang, Lester, 2006).

Psychological adaptation to life in late adulthood is a necessary condition for facilitating successful aging (Kim, Park, 2017). The basis of enjoying a satisfying life in the senior period involves functioning according to the principles of human development, as well as paying attention to particular factors and elements of lifestyle (Dezutter et al., 2013, Westerhof, Bohlmeijer, McAdams, 2017).

\section{References}

Alexandre, T. D. S., Cordeiro, R. C., \& Ramos, L. R. (2009). Factors associated to quality of life in active elderly. Revista de Saúde Pública, 43(4), pp. 613-621. DOI: http://dx.doi. org/10.1590/S0034-89102009005000030.

Beutel, M. E., Glaesmer, H., Decker, O., Fischbeck, S., \& Brähler, E. (2009). Life satisfaction, distress, and resiliency across the life span of women. Menopause, 16(6), pp. 1132-1138. DOI: http://dx.doi.org/10.1097/gme.0b013e3181a857f8.

Beutel, M. E., Glaesmer, H., Wiltink, J., Marian, H., \& Brähler, E. (2010). Life satisfaction, anxiety, depression and resilience across the life span of men. The Aging Male, 13(1), pp. 32-39. DOI: http://dx.doi.org/10.3109/13685530903296698.

Bowling, A. (2007). Aspirations for older age in the 21 st century: What is successful aging? 
The International Journal of Aging and Human Development, 64(3), pp. 263-297. DOI: http://dx.doi.org/10.2190/L0K1-87W4-9R01-7127.

Brudek, P. (2017). Mediacyjna rola bilansu życiowego w związkach cech osobowości i jakości życia osób starszych. Gerontologia Polska, 25, pp. 168-175.

Dezutter, J., Wiesmann, U., Apers, S., \& Luyckx, K. (2013). Sense of coherence, depressive feelings and life satisfaction in older persons: a closer look at the role of integrity and despair. Aging \& Mental Health, 17(7), pp. 839-843. DOI: http://dx.doi.org/10.1080/1 3607863.2013.792780.

Diener, E. D., Emmons, R. A., Larsen, R. J., \& Griffin, S. (1985). The satisfaction with life scale. Journal of personality assessment, 49(1), pp. 71-75.

Dziurowicz-Kozłowska, A. (2002). Wokół pojęcia jakości życia. Psychologia Jakości Życia, 2(1), pp. 77-99.

Erikson, E. H. (2002). Dopetniony cykl życia. Poznań: Dom Wydawniczy Rebis.

Finogenow, M. (2008). Psychologiczne uwarunkowania zadowolenia z życia w wieku emerytalnym-wyniki modelowania równań strukturalnych. Polskie Forum Psychologiczne, 13 (2), pp. 82-95.

Fredrickson, B. (2001). The role of positive emotions in positive psychology: The broaden-and build theory of positive emotions. American Psychologist, 56, pp. 218-226.

Halicka, M. (2004). Satysfakcja życiowa ludzi starych: studium teoretyczno-empiryczne. Białystok: Akademia Medyczna.

Havighurst, R. (1981). Developmental tasks and education. New York: Longman and Green.

Hutteman, R., Hennecke, M., Orth, U., Reitz, A. K., \& Specht, J. (2014). Developmental Tasks as a Framework to Study Personality Development in Adulthood and Old Age. European Journal of Personality, 28(3), pp. 267-278. DOI: https://DOI.org/10.1002/per.1959.

Juczyński, Z. (2009). Narzędzia pomiaru w psychologii i promocji zdrowia. Warszawa: PTP.

Kim, S., \& Park, S. (2017). A Meta-Analysis of the Correlates of Successful Aging in Older Adults. Research on Aging, 39(5), pp. 657-677. DOI: http://dx.doi. org/10.1177/0164027516656040.

Kozerska, A. (2015). Edukacja seniorów w kontekście koncepcji pomyślnego starzenia się: kontrowersje i wątpliwości. Edukacja Dorosłych, 2, pp. 23-36.

Liu, Y., Wang, Z. H., \& Li, Z. G. (2012). Affective mediators of the influence of neuroticism and resilience on life satisfaction. Personality and Individual Differences, 52(7), pp. 833-838. DOI: http://dx.doi.org/10.1016/j.paid.2012.01.017.

Luthans, F., Vogelgesang, G. R., \& Lester, P. B. (2006). Developing the psychological capital of resiliency. Human Resource Development Review, 5(1), pp. 25-44. 
Magee, C. A., Miller, L. M., \& Heaven, P. C. (2013). Personality trait change and life satisfaction in adults: The roles of age and hedonic balance. Personality and individual differences, 55(6), pp. 694-698. DOI: http://dx.doi.org/10.1016/j.paid.2013.05.022.

Newman, B. M., Newman, Ph. R. (1984). Development through life. Homewood: The Dorsey Press.

Ogińska-Bulik, N., Juczyński, Z. (2008). Skala pomiaru prężności - SPP-25. Nowiny Psychologiczne. 3, pp. 39-56.

Ogińska-Bulik, N. (2010). Prężność a jakość życia młodzieży. Psychologia Jakości Życia, 1, pp. 233-247.

Ogińska-Bulik, N. (2014). Prężność psychiczna a zadowolenie z życia osób uzależnionych od alkoholu. Alkoholizm i Narkomania, 27(4), ss. 319-324.

Ogińska-Bulik, N., Zadworna-Cieślak, M., Rogala, E. (2015). Rola zasobów osobistych w podejmowaniu zachowań zdrowotnych przez osoby w wieku senioralnym. Problemy Higieny i Epidemiologii, 96(3): pp. 570-577.

Pavot, W., Diener, E. (2009). Review of the Satisfaction with Life Scale. In: Diener E. (eds.) Assessing Well-Being. Social Indicators Research Series, vol. 39 (pp. 101-117). Dordrecht: Springer.

Sęk, H. (2008). Udział pozytywnych emocji w osiąganiu zdrowia. In: I. Heszen, J. Życińska (red.), Psychologia zdrowia w poszukiwaniu pozytywnych inspiracji (pp. 73-88). Warszawa: Wydawnictwo SWPS.

Świerżewska, D. (2010). Satysfakcja z życia aktywnych i nieaktywnych osób po 60. roku życia. Psychologia Rozwojowa, 15(2), 89-99.

Villar, F. (2012). Successful ageing and development: The contribution of generativity in older age. Ageing \& Society, 32(7), 1087-1105.

Westerhof, G. J., Bohlmeijer, E. T., \& McAdams, D. P. (2017). The Relation of Ego Integrity and Despair to Personality Traits and Mental Health. Journals of Gerontology Series B: Psychological Sciences \& Social Sciences, 72(3), pp. 400-407. DOI: http://dx.doi. org/10.1093/geronb/gbv062.

Zadworna-Cieślak M., Marszałek, M. (2017). Różne oblicza starości. In: V. Tanaś, W. We1skop (eds.), Człowiek wobec zagrożeń współczesności (pp. 173-183), Łódź: Wydawnictwo Naukowe Wyższej Szkoły Biznesu i Nauk o Zdrowiu.

Zadworna-Cieślak, M. (2017). Developmental tasks' attainment in late adulthood - the construction of a new psychometric tool, Gerontologia Polska, 25, 156-162.

Zielińska-Więczkowska, H., \& Kędziora-Kornatowska, K. (2010). Determinanty satysfakcji życiowej w późnej dorosłości-w świetle rodzimych doniesień badawczych. Psychogeriatria Polska, 7(1), pp. 11-16. 